
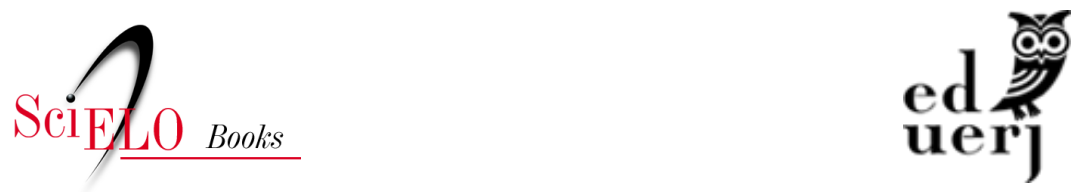

\title{
10. Entrevista com Eurídice Figueiredo
}

\author{
Vanessa Massoni da Rocha
}

\section{SciELO Books / SciELO Livros / SciELO Libros}

ROCHA, V. M. Entrevista com Eurídice Figueiredo. In: Tradução em (ent)revista: Simone Schwarz-Bart e as tradutoras brasileiras [online]. Rio de Janeiro:

EDUERJ, 2021, pp. 81-102. Letras UERJ collection. ISBN: 978-65-991111-5-0. https://doi.org/10.7476/9786599111150.0010.

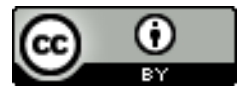

All the contents of this work, except where otherwise noted, is licensed under a Creative Commons Attribution 4.0 International license.

Todo o conteúdo deste trabalho, exceto quando houver ressalva, é publicado sob a licença Creative Commons Atribição 4.0.

Todo el contenido de esta obra, excepto donde se indique lo contrario, está bajo licencia de la licencia Creative Commons Reconocimento 4.0. 


\section{0.}

\section{Entrevista com Eurídice Figueiredo}

1. A tradução do romance guadalupense Ti Jean foi publicada no ano de conclusão de seu doutorado em Letras Neolatinas na UFRJ, em 1988. Nessa época, você já atuava como professora da UFF há seis anos. Como o projeto de tradução da obra Ti Jean se entrecruza em seu percurso universitário? Você já conhecia a obra? A tradução foi uma iniciativa pessoal? $\mathrm{O}$ romance integrava suas pesquisas?

Fui convidada para uma reunião na Francisco Alves, a editora que publicou a tradução, pela professora Lilian Pestre de Almeida, minha orientadora no mestrado e quem me indicou à editora para traduzir a obra. A conversa foi com Eliane Zagury, uma das responsáveis pelo setor de tradução da Francisco Alves na época. Imagino que a iniciativa para a tradução tenha sido da Eliane Zagury. Comecei a tradução durante o doutorado... Na verdade, eu não sei te dizer quando comecei nem quando terminei. Eu fiz a tradução, entreguei e passou um tempo enorme; eu não tive nenhuma notícia, nada. Não tive nenhuma participação no processo de edição e de editoração do 
livro nem no de revisão. Eu entreguei, eles me pagaram o que tinham que me pagar, não me lembro quanto, e, de repente, um dia, eu vi o livro na livraria. Quer dizer, esse título, por exemplo, Joãozinho no Além, eu não tenho nada a ver com isso. Eu sempre detestei esse nome e até me envergonho desse título. Quando foi conversado com a Eliane Zagury, ela achou que não se devia conservar o nome do personagem Ti Jean. Quando eu traduzi o texto, ele virou Joãozinho. Mas este "no além" foi invenção da editora. Foram eles que decidiram.

A obra Ti Jean não fazia parte do meu projeto de doutorado ${ }^{1}$. Foi publicada ao término do meu doutorado por coincidência. Na verdade, eu devo ter entregado a tradução lá para 1985 ou 1986. Demorou muito para sair. Eu tinha lido o romance porque foi o período em que comecei a me interessar pela literatura antilhana. Concluí, em 1979, um mestrado sobre Césaire ${ }^{2}$. No início dos anos 1980, eu estava lendo literatura antilhana. Então, eu tinha lido os livros de Simone Schwarz-Bart e, por isso, que a Lilian achou que eu seria capaz de traduzir o romance.

2. Quais os caminhos que levam uma professora universitária e pesquisadora a se tornar tradutora? Sair da zona de conforto? Olhar a obra literária sob outras perspectivas? Tornar a obra conhecida para leitores não francófonos?

Na verdade, não foi nada premeditado. Me convidaram para isso e aceitei. Eu voltei para o Brasil em 1973, depois de ter passado dois anos na França e um na Inglaterra, cheguei ao Rio de Janeiro em 1974. Nos anos 1970 e 1980, trabalhei como intérprete em muitas ocasiões.

I Sob orientação de Maria do Carmo Pandolfo, Eurídice obteve, em 1988, o título de doutora em Letras Neolatinas na UFRJ, com a tese intitulada Jeanne Hyvrard: escritura como busca de identidade, desenvolvida entre 1982 e 1988.

2 Sob a orientação da professora Lilian Pestre de Almeida, Eurídice obteve, em 1979, o título de mestre em língua e literatura francesa na UFRJ, com a dissertação intitulada Do negro à negritude: significado do teatro histórico de Aimé Césaire, desenvolvida entre 1975 e 1979. 
Chegava um francês ao Rio, e me chamavam para traduzir. Traduzi Ionesco, Francis Bebey (poeta e cantor de Camarões, convidado pela professora Lilian), Sarah Kofman (que ministrou um curso na Universidade Federal Fluminense), assim como palestras feitas por Édouard Glissant na UFF e na UERJ.

Eu não me considero tradutora. Traduzi na época do doutorado alguns artigos do Lévi-Strauss, que foram publicados em livro organizado pela minha orientadora de doutorado Maria do Carmo Pandolfo. Traduzi dois ou três artigos ${ }^{3}$ do livro Antropologia Estrutural II e este romance. Nada mais. Não me considero de modo algum tradutora, não gosto especialmente de ser tradutora e nem de ser intérprete. Deixei de ser intérprete nos anos 1990 porque não é uma atividade que me deixe muito confortável, embora ocasionalmente possa traduzir alguém em um evento, numa mesa redonda. Traduzir em cabine, por exemplo, parei há muitos anos. Não é uma atividade que eu queira fazer.

\section{Por quanto tempo se prolongou o processo de tradução?}

Não me lembro bem, mas diria que foi um ano. Eu tinha um prazo e eu cumpri o prazo.

4. Durante o processo de tradução, você teve a curiosidade ou o método de trabalho de consultar uma tradução anterior de Ti Jean em outro idioma? Em 1986, Estela dos Santos Abreu traduziu Pluie et vent sur Télumée Miracle. Ler a primeira tradução de Simone Schwarz-Bart para o português foi uma espécie de percurso para a sua tradução de Ti Jean?

Quando eu concluí minha tradução, a tradução da Estela ainda não tinha sido publicada. Não tive nenhum contato com nenhuma outra

3 Eurídice Figueiredo traduziu os artigos "O sexo dos astros", "Os cogumelos na cultura" e "Relações de simetria entre ritos e mitos de povos vizinhos", da obra Anthropologie Structurale Deux (1973), de Claude Lévi-Strauss, sob a supervisão de tradução e a coordenação de Maria do Carmo Pandolfo. A tradução brasileira da obra se intitula Antropologia Estrutural II e foi publicada pela editora Tempo Brasileiro em 1976. 
obra da escritora. Eu me lembro da publicação de $A$ ilha da chuva e do vento, mas não tive acesso a ela durante o percurso de tradução. Também não tive acesso a Simone Schwarz-Bart.

5. Como sua condição de professora e de pesquisadora da literatura antilhana repercutiu na tradução? Em outras palavras, como seu interesse pela literatura antilhana condicionou o processo de tradução?

Não saberia dizer porque na época eu tinha pouca experiência de leitura. Estava lendo Patrick Chamoiseau, Edouard Glissant, Simone Schwarz-Bart. Gosto muito do Pluie et vent sur Télumée Miracle. Você tem certa percepção de um ambiente, da presença do folclore, da oralidade e de mitos. É inegável que isto auxilia na compreensão da obra, mas eu era uma jovem pesquisadora naquele momento.

\section{O que podemos depreender do fato de Ti Jean ter sido sua única} tradução romanesca? Como você vivenciou esse processo? Como foi a recepção da tradução?

Eu realmente não me considero tradutora. Fiquei um pouco decepcionada com a demora para a publicação e por terem optado por este título que achei horrível. Eu mesma fico insatisfeita. Na época era muito mais difícil traduzir do que agora porque, com a internet, com as ferramentas de busca, você consegue descobrir mais facilmente determinados elementos, como o vocabulário da fauna e da flora. Eu me lembro da dificuldade em traduzir, por exemplo, a fruta prune de cythère. Prune, como todos sabemos, é ameixa. Cythère me evocava o quadro $O$ embarque pour Cythère, de Watteau, de 1718. Mas uma coisa não se encaixava na outra. Eis que descubro se tratar da fruta cajá-manga. Foi uma descoberta difícil. Jamais teria pensado nisso num primeiro momento.

Na época, você não tinha como saber, por exemplo, a tradução de uma planta específica. Você tinha a descrição em um dicionário francês, quando você encontrava, porque muitas vezes você não encontrava. 
Era um sufoco porque você não tinha como descobrir que árvore era aquela, que fruta era aquela e que peixe era aquele. Eu me senti muito mais frustrada do que realizada ou feliz no processo de tradução. Com relação à recepção, houve uma resenha publicada no Jornal do Brasil em que o resenhista me criticou porque eu traduzi "lapider" por "lapidar", enquanto poderia ter traduzido por "apedrejar", uma palavra muito mais corrente na língua portuguesa. Eu me lembro deste pequeno detalhe que evidentemente me deixou ainda mais irritada com tudo. Depois eu reli a tradução e observei que o livro tem vários pequenos erros de impressão, várias gralhas, além dos defeitos eventuais da minha própria tradução.

\section{Você tem lembrança da repercussão da tradução em termos de vendagem de exemplares?}

Não tenho.

\section{Como você analisa o interesse por traduções de obras de Simone Schwarz-Bart na década de 1980 no Brasil?}

A sensação é a de que houve pouco impacto, tanto as obras $A$ ilha da chuva e do vento e Joãozinho no Além, de Simone Schwarz-Bart, quanto, por exemplo, o romance Le Quatrième siècle, de Édouard Glissant, que foi traduzido pela professora Cleone Augusto Rodrigues, da Universidade Federal do Rio de Janeiro, como Quarto século em 1986. A própria Estela traduziu alguns livros do haitiano René Depestre. Depois houve a tradução do Texaco, de Patrick Chamoiseau, pela Rosa Freire d'Aguiar em 1993. Mais tarde houve a tradução do escritor brasileiro-canadense Sergio Kokis, Le Pavillon des miroirs, traduzido como A casa dos espelhos. A minha impressão é que nenhum destes romances teve muito impacto. 
9. O escritor canadense Jacques Poulin publicou o romance $L a$ traduction est une histoire d'amour em 2006. Nesse romance, ele revela curiosidades do processo de tradução da tradutora Marine e do escritor Waterman, dentre as quais se destaca o fato de a tradutora usar as roupas do autor, visitar sua casa e andar por caminhos por ele percorridos. Nesse sentido, eu te pergunto: A tradução é uma história de amor?

No meu caso, não. O fato de eu não ter me sentido confortável nem satisfeita em torno deste processo, não quer dizer que eu não goste do livro. Eu continuei gostando da Simone Schwarz-Bart e desses romances. Ela parou de escrever, ficou anos sem escrever nada e eu até achei triste porque eu gostava muito dos livros dela, mas eu não me identifico com a afirmação de Poulin.

\section{Como você definiria a arte da tradução: reescrita?}

Eu concordo com a linha de pensamento de Haroldo de Campos segundo a qual toda tradução é uma recriação. Não tenho dúvida de que o que eu busquei e o que me parece mais importante na tradução de romance foi conservar certo ritmo de frase. Isto é o fundamental. Nem falo de poesia, porque seria incapaz de traduzir um poema. A tradução tem que ser lida num ritmo agradável de frase, a frase precisa soar bem. Você deve tentar recriar determinada rítmica da prosa do autor, mas você deve recriar porque evidentemente não existe nem fidelidade nem traição. A tradução é sempre um processo de recriação.

11. Você acabou de dizer que seria incapaz de traduzir a poesia. Por que, para você, o romance parece um gênero mais acessível? Você já imaginou a possibilidade do caminho inverso, de tradução do português para o francês?

Do português para o francês não, porque, em princípio, você traduz sempre para a sua língua materna. Traduzir para uma língua que não é a sua língua materna é sempre um processo mais difícil. Eu faço isto para texto meu, texto acadêmico, mas, de preferência, eu não 
traduzo. Quando eu tenho que fazer um texto em francês, eu faço direto em francês, eu acho muito difícil traduzir meu próprio texto para o francês. Os textos que publiquei em francês foram escritos em francês, com a exceção de um texto recente para o qual paguei uma tradução porque não estava querendo traduzir.

Quando eu falo de poesia, eu falo sobretudo de poesia rimada, com métrica. Isto realmente eu sou incapaz de fazer. Agora há romances mais difíceis e outros mais fáceis. Quanto mais elaborada a língua/ linguagem do escritor, mais difícil traduzir. É mais difícil traduzir Texaco, por exemplo, do que traduzir um romance de linguagem mais simples. No caso da Schwarz-Bart, ela não é tão difícil quanto o Chamoiseau ou o Glissant, porque usa menos expressões oriundas do crioulo. Por outro lado, este romance apresenta dificuldades enormes em torno da variedade lexical, principalmente de fauna e flora, como eu já falei. E também é uma linguagem muito poética, por isto que eu digo que o meu cuidado foi muito menos com a questão puramente lexical do que com a rítmica da frase. Se você tem uma frase capenga você mata o romance.

\section{Você poderia revelar algumas curiosidades do seu processo de tradução? Havia um momento específico do dia, um lugar, um ritual, uma mania?}

Não. Nada. Eu nunca tive ritual para nada, para escrita, para pesquisa, para nada. Eu não sou uma pessoa de ritual. Eu trabalho nos momentos em que eu tenho tempo para trabalhar.

\section{Você tem lembrança de organizar sua rotina em momentos para a tese de doutorado e outros para a tradução?}

Eu não estava escrevendo a tese quando eu traduzi. A tese eu defendi em 1988, e eu só empreendi um ritmo de escrita nos últimos dois anos. A tradução foi anterior à tese. 
14. Nesse mesmo romance de Poulin, há a definição de tradução como transporte, transporte de língua ou transporte amoroso através da citação de Albert Bensoussan presente na epígrafe. Então eu te pergunto: para você, a tradução é um transporte? Que tipo de transporte?

Mais uma vez, eu não sou especialista nem na prática nem na teoria da tradução, mas é claro que há uma espécie de transporte ou de mediação. O tradutor exerce este papel de mediador ou de transportador na medida em que você traz aquela cultura, aquela literatura para outro espaço, outra área literária e outra linguística. $\mathrm{O}$ escritor Salman Rushdie escreve em seu livro Imaginary Homelands que os imigrantes como ele são homens traduzidos, porque a etimologia da palavra traduzir é atravessar, cruzar. Ao escrever em inglês sobre uma cultura asiática, ele provoca essa relação transcultural. Você está sempre de alguma maneira viajando, está trazendo uma literatura, uma cultura para dentro da sua cultura.

15. Antoine Berman, na obra L'épreuve de l'étranger, afirma que "a essência da tradução é ser uma abertura, diálogo, mestiçagem, descentramento" (2011, p. 16). Qual a sua opinião sobre essa afirmação? A tradução encarna o que o autor considera ser "a violência da mestiçagem" (2011, p. 16)?

Isto aí é um pouco de literatura do Berman. De qualquer modo, a experiência da tradução é sempre uma experiência de hibridismo porque você lida com duas línguas e eventualmente você comete alguns deslizes. Você está tão familiarizado com determinada palavra na língua estrangeira que você tem a impressão de que ela existe na sua língua materna. Toda tradução tem algum deslize. Com certeza, eu fiz isto também, porque você está nesse entre-lugar das línguas. Durante alguns anos falei francês e vivi em francês, como nos dois anos que passei na França, e, mesmo depois, durante os onze anos em que trabalhei na Aliança Francesa. 
16. Estela dos Santos Abreu afirmou em entrevista: "Não gosto de traduzir autor morto. Com o vivo, eu pergunto, troco ideias. Com um morto não posso fazer isso" (apud Melo, 2009, s/p). Qual a sua opinião sobre o tema? $\mathrm{O}$ trabalho a quatro mãos entre autor e tradutor é essencial para a tradução? O que você apontaria como vantagens ou inconvenientes?

Em princípio, eu acho que você não necessita falar com o autor no processo de tradução, assim como você não precisa falar com o autor para ler ou interpretar um texto dele. É claro que, em textos excessivamente complexos, se o autor participar e colaborar, é maravilhoso. Há o caso bastante clássico de Guimarães Rosa com seu tradutor alemão. Em casos complexos como o de Rosa, de Joyce e de muitos outros, é desejável um trabalho de parceria autor-tradutor ao longo do processo de tradução. Mas não necessariamente. O Macunaíma, por exemplo, foi traduzido quando Mário de Andrade já havia morrido. Não é possível pensar nesse escritor vivo sempre, até porque há tantos escritores mortos que necessitam ser traduzidos.

17. Desde o doutorado, a estética da oralidade (preconizada por Glissant e Chamoiseau) figura como um tema central de suas reflexões. Como você interpreta o desafio da tradução da oralidade em Ti Jean?

Em Simone Schwarz-Bart, esta oralidade é menos acentuada do que em Chamoiseau, por exemplo. Ela tem uma linguagem poética, ancorada na oralidade, ou seja, trata-se de uma linguagem muito próxima à vida antilhana, à vida crioula. A estética da oralidade de Patrick Chamoiseau, Raphaël Confiant e Édouard Glissant, principalmente nos primeiros romances, se distingue da de Schwarz-Bart porque ela usa menos o crioulo. 
18. Alguns críticos, como Mariella Aïta (2010, 2015), reconhecem que Schwarz-Bart escreve na língua franco-crioula, língua marcada por mestiçagens linguísticas que se reconhecem, por exemplo, nos temas, na entonação e na sintaxe utilizados. Você reconhece esta língua? Como é possível para a arte da tradução espelhar a riqueza de línguas em contato no âmbito do texto? Como explicitar a presença do crioulo no discurso em francês?

Para quem não sabe, crioulo já é um problema. Chamoiseau e Glissant, muito mais do que Schwarz-Bart, usam alguns processos de tradução no meio da frase, vários procedimentos que eles usam para tornar legível aquilo que não seria legível para o leitor francês que desconhece o crioulo. O que você nota é certa ruptura do padrão da norma francesa. Os franceses são, de certa maneira, mais rígidos do que nós que somos estrangeiros e falamos francês como língua estrangeira. Quando foi publicado o livro do Chamoiseau, Biblique des derniers gestes, uma amiga francesa questionou o fato de a palavra biblique, um adjetivo, figurar como substantivo no título da obra. Acredito que a gente tenha mais abertura para este tipo de linguagem criativa ou mais povoada de neologismos. Aparentemente neologismos, mas, na verdade, adaptações do crioulo, crioulismos. O português do Brasil é muito aberto também, muito aberto para criações. Há uma flexibilidade na língua portuguesa do Brasil que faz com que a gente aceite mais esta flexibilização, digamos, do francês como ele é praticado pelos escritores antilhanos que romperam bastante com a língua padrão.

Quando você traduz, espelhar as línguas em contato é muito difícil. Não existe o crioulo no Brasil. É a mesma situação de um romance que tem a linguagem dos negros nos Estados Unidos, como você vai traduzir para o português? Não existe a correspondência. No romance Texaco, que foi traduzido pela Rosa Freire d'Aguiar, uma tradutora experiente, que traduz muito, a tradutora acabou reduzindo a linguagem do Chamoiseau a uma língua bastante padronizada do português no Brasil. Realmente é muito difícil. O que alguns tradutores fazem, 
tanto com a literatura brasileira na França quanto na dos antilhanos para o Brasil, é deixar algumas palavras na língua original, eventualmente com glossário no final ou com alguma explicação de pé de página para, de alguma maneira, provocar um impacto no leitor, uma espécie de estranhamento que a língua deles provoca no leitor francês. De alguma maneira, é preciso causar um estranhamento. Se você padronizar o texto, você mata a estilística do autor, esta que é a questão.

19. Insistindo ainda nesse tema, Mariella Aïta afirma que "para Simone Schwarz-Bart chegar a um resultado significa aprender a passar, nesse processo de retranscrição, por diversas camadas linguísticas: a camada crioula, a camada francesa, a camada crioulo-francesa e, em seguida, o produto, o novo termo, a nova língua” (2010, p. 23).

Como a tradução vislumbra essas camadas linguísticas?

Primeiramente, isto já é uma elaboração teórica de alguém que estudou a questão, o que eu não fiz. Depois, eu teria que ter uma leitura mais recente da Schwarz-Bart para poder pensar neste tema. Eu acho que, na prática da tradução, você deve tentar provocar o efeito que o original provoca no leitor, ainda que sempre seja diferente: o leitor é diferente, de outra área linguística, você está lidando, portanto, com leituras diferentes. $\mathrm{Na}$ prática, estas camadas não existem, você tem um prosa que precisa ser vertida. E você precisa, de alguma maneira, se apropriar desta prosa, para poder dizer algo correspondente na sua língua.

20. Antoine Berman afirma que escritores francófonos como Édouard Glissant e Simone Schwarz-Bart encarnam o trabalho ambivalente, essencial à tradução, "para forçar sua língua a incorporar-se de estranheza, forçar a outra língua a transitar na sua língua materna" (2011, p. 18). Para Berman, eles imprimem sua "estranheza" na língua francesa ao mesmo tempo que tendem a empregar uma língua 
mais "pura" que a da França. Como você avalia essa dicotomia? Esses escritores seriam tradutores?

Antonine Maillet, que é uma escritora da Acádia, no Canadá, ganhou o prêmio Goncourt com Pélagie-la-Charrette. Quando ela foi entrevistada por Bernard Pivot, ela disse que os franceses esqueceram muitas palavras usadas por Rabelais e que ela usava muitas palavras que estavam em Rabelais. Palavras da língua francesa. Considero que Antonine Maillet entraria neste mesmo circuito de escritores que vão beber um pouco nessas fontes muito antigas do francês. É preciso levar em consideração que o francês que foi trazido para as Américas foi o francês de outra época, um francês regional. Não é a mesma língua que é falada hoje na França. A língua na França evoluiu de determinada maneira. A língua que foi trazida para a Acádia, o Quebec e as Antilhas é uma língua do século XVII, XVIII, de determinadas regiões de onde vieram os colonizadores; muitas vezes, uma língua que não era a língua padrão francesa. O próprio crioulo é uma derivação desta língua francesa regional e arcaica, se comparada à língua dos dias de hoje. Então, o que estes escritores fazem é trabalhar uma língua francesa que parece arcaica como todas as línguas das Américas, línguas trazidas para o continente numa outra época e teve uma evolução diferente do que estas línguas tiveram na Europa. Os escritores antilhanos, e também os da Acádia e do Quebec, utilizam esta língua/linguagem a partir de uma língua que existiu nessas regiões da América e que foi conservada, por meio de expressões, palavras e formas de construção de frases, que não existem mais na França. De alguma maneira, a tradução deve lidar com isso. Alguns escritores francófonos reclamam que os franceses gostam muito do fantástico, do realismo mágico dos escritores de língua espanhola porque eles são traduzidos para o francês. Quando são os escritores francófonos que usam uma língua atravessada por suas línguas de origem, portanto um francês fora da norma padrão, os franceses não aceitam sob o argumento de que isto não é francês. $\mathrm{O}$ 
francês é muito variado, dependendo da região. Um escritor africano, por exemplo, vai escrever num francês completamente diferente do francês da Martinica ou do Quebec, graças às variações e ao vocabulário ligado à fauna, flora, pontos geográficos, tradições alimentares, tradições culturais, tradições religiosas, entre outras, que cada região apresenta. $\mathrm{O}$ escritor vai carrear para sua escrita estes elementos culturais da sua comunidade. $O$ tradutor precisa lidar com uma língua que tem história, que, ao longo dessa história, se moldou de maneira diferente; o tradutor deve estar aberto para esta experiência.

21. A oralitura está amplamente representada em obras caribenhas. $\mathrm{Na}$ obra Construção das identidades pós-coloniais na literatura antilhana, você salienta que "Schwarz-Bart faz um trabalho inspirado na literatura oral tradicional, o que dá ao romance um aspecto fragmentário, de colagem de várias histórias, com $\mathrm{Ti}$ Jean funcionando como um fio condutor. No prólogo do romance, a autora assinala a importância do trabalho incessante da língua, da germinação dos contos, que são a sombra e o mistério dos negros" (1998, p. 137). Como traduzir a oralitura manifestada nos contos e nos provérbios? Que lembranças você tem sobre os provérbios no romance em questão?

Na obra da Schwarz-Bart, eu vejo mais a utilização dos contos e de certo folclore, no sentido geral. Dentro da história vão se acumulando várias histórias de inspiração claramente popular. O livro é uma espécie de amálgama de contos, de histórias; neste sentido, ele é crioulo, apresenta marcas da crioulidade. Muito mais por isso do que propriamente numa linguagem com crioulismos, que, na minha opinião, ela não tem. $\mathrm{O}$ francês dela, neste sentido, é mais fácil de ser traduzido do que Texaco. Ela não tem expressões como "L'en-ville" ou outras similares. Com relação aos provérbios, trabalhei a partir da improvisação. Como já disse, não me considero uma verdadeira tradutora. 
22. Qual seu procedimento diante de um termo desconhecido a ser traduzido: você interrompia o fluxo de tradução para pesquisá-lo ou assinalava o termo para buscá-lo posteriormente?

Todo tradutor marca aquela palavra de alguma maneira e continua. Se você parar, acho que você não continua nunca mais. Tradutores que eu já ouvi dizem a mesma coisa: se houver uma pedra no meio do caminho, você marca a pedra e deixa para pensar nela depois. De qualquer modo, ao traduzir você sempre precisa voltar. É uma regra que todos seguem: traduzir e fazer depois uma leitura sem o original para ver como aquilo soa em português. Neste sentido, já há duas traduções. Na época não se usava computador, eu primeiro traduzi escrevendo a mão e depois eu bati à máquina e entreguei datilografado. A primeira tradução foi em um caderno que eu não guardei. Depois eu fechei o original e fui lendo, relendo, corrigindo.

23. Que tipo de dicionários você utilizou? Como solucionar alguns entraves que se impõem ao processo de tradução? Você tirava dúvidas com alguém em particular?

Não tinha ninguém para perguntar, não. São ruins os dicionários do francês para o português. Até hoje, eu uso muito o dicionário francês-francês para entender alguma palavra. Eu tinha um dicionário de crioulo-francês que eu tinha comprado na Martinica, que foi pouco útil. Eu não me lembro de ter perguntado para alguém. Eu tentava descobrir o que era consultando livros, mas nem sempre fui muito feliz.

24. O livro apresenta algumas canções. Como teu processo de tradução leva em conta o ritmo musical de Schwarz-Bart?

(Eurídice folheia a minha edição de Joãozinho no Além, disposta ao meu lado no sofá, para encontrar as músicas das quais não mais se lembra. Sua expressão denuncia a alegria do reencontro com o texto traduzido na segunda metade da década de 1980. Busca as músicas e conta quantas vezes pode repertoriá-las com o avançar irregular 
das páginas. Depois me diz: - Tem algumas músicas, né? Mas não muitas. Algumas.

O tempo da entrevista parece se suspender com o reencontro com o texto. Eu me calo e observo suas feições e alguns comentários sobre as músicas que encontra. Daí ela confessa: - Você está me fazendo falar de uma coisa que eu fiz há mais de trinta anos. (risos) Não tenho memória para isso, não.)

Penso no texto sem valorizar a métrica da música. A preocupação com certo ritmo da frase sempre esteve presente porque eu a considero fundamental. Mesmo num texto ensaístico que eu escrevo, penso sempre no ritmo da frase. No romance que traduzi, eu lia em francês e captava o som, a sonoridade, a rítmica, valorizando a base de contos orais que permeia a obra. Eu traduzia e ordenava as palavras pensando na frase apenas.

25. A canadense Monique Bouchard optou pela existência de um glossário ao fim de um estudo sobre a obra Pluie et vent sur Télumée Miracle. Na sua tradução, não há glossário, tampouco nota explicativa do tradutor. Por que você optou por não utilizar esses paratextos? Quando eles te parecem fundamentais? Quando são dispensáveis?

O glossário é usado sempre em último caso. O romance é um gênero que não pede nem nota de pé de página nem glossário. Em princípio, não deve apresentar nenhum dos dois recursos. Se a tradução for muito complexa, os tradutores fazem uso deles caso a editora concorde. $\mathrm{O}$ tradutor não é totalmente autônomo. Eu orientei uma tese de doutorado ${ }^{4}$ sobre a tradução e a recepção de Milton Hatoum na

4 Trata-se da tese de doutorado de Maria Inês Coimbra Guedes, defendida em 2015: A literatura brasileira na França: tradução e recepção de Dois irmãos e Órfãos do Eldorado de Milton Hatoum. 
França. A Inês entrevistou os tradutores ${ }^{5}$, e a gente percebe que eles não são totalmente livres. No meu caso, me impuseram o título do romance. Você não dispõe de liberdade total e nem pode impor suas preferências. Na tradução do Ti Jean, paratextos não me pareceram necessários. Em outras obras, trata-se de uma necessidade. Foi o que fez, por exemplo, o tradutor do Macunaíma. A tradução espanhola que eu vi uma vez na Argentina do romance Texaco apresentava um glossário.

26. O romance, de contornos fantásticos latentes, narra as peripécias do herói Joãozinho em percorrer diversos mundos após ter-se deixado engolir pela Fera para salvar sua terra de origem. Quais as maiores desafios na tradução desse romance no que tange às peripécias extraordinárias dos personagens?

Não me lembro.

27. Por ser um texto do realismo fantástico, a tradução do texto apresentou uma dificuldade complementar? Pergunto isso porque se trata de uma narrativa que rompe com o linear e que se organiza em histórias espiraladas que se imbricam umas nas outras, o que torna a leitura da obra uma atividade mais complexa.

Eu não me lembro de ter tido dificuldade com relação a isso. É preciso se levar em consideração que já faz mais de trinta anos. A dificuldade de que eu me lembro remete ao vocabulário de fauna e flora, com palavras específicas do mundo antilhano que eu não conhecia. Encontrar soluções para este vocabulário foi o problema principal. No mais, o fato de ser fantástico, do personagem estar no mundo dos mortos, ir para a África, do ponto de vista da tradução, não creio que isto tenha um impacto.

5 Cécile Tricoire, tradutora de Dois irmãos, e Michel Riaudel, tradutor de Órfãos do Eldorado. As entrevistas foram realizadas, respectivamente, em abril e agosto de 2014. 
28. Como tradutora, você optou pela tradução do nome dos personagens e das cidades presentes no romance (Fundo-Zumbi (p. 182), Bordéus (p. 91), Egê, Ananzê (p. 95), Eloísa (p.31)). Trata-se de uma iniciativa do tradutor, uma diretriz da editora? Pergunto isto porque a personagem Télumée Miracle assume a identidade de Télumée Milagre na tradução de Estela Abreu, embora na edição espanhola seja Telumea.

Como regra de tradução que depois eu aprendi nos cursos de tradução que fiz e que ministrei no programa de pós-graduação da Universidade Federal Fluminense, você não traduz os nomes próprios. No entanto, no encontro que eu tive com a Eliane Zagury e com a Lilian, elas consideraram que o nome Ti Jean seria um entrave para a leitura, ainda mais com o apóstrofo do "l'horizon". Então, se decidiu que seria traduzido. Eu, hoje, não traduziria. Isto é um produto de um determinado momento há mais de trinta anos.

Bordéus, por exemplo, normalmente se traduz. Segundo o padrão ABNT (Associação Brasileira de Normas Técnicas), a cidade de Bordeaux é Bordéus. Agora, Fundo-Zumbi poderia ter ficado Fond-Zombi, não precisaria ter traduzido. Seria difícil traduzir Télumée porque não existe este nome em português. Estela manteve o Télumée, mas traduziu o sobrenome para Milagre. Não se conservou o nome original.

A questão dos russos ilustra este debate. Eles têm tantas versões para o mesmo nome que você se perde quando você lê. Eles têm três nomes, um apelido, o feminino no sobrenome, o que desencadeia uma confusão. Às vezes você opta, na tradução, por não usar todos os nomes usados pelo autor, para simplificar a leitura. 
29. Sua tradução completa em 2018 trinta anos de publicação. Você já a releu? Estes trinta anos levam a reavaliar algum aspecto dessa tradução? Que balanço você faz da tradução?

Eu reli quando o livro foi publicado. Reli e anotei errinhos, gralhas e algumas traduções que poderia ter feito de maneira diferente. Depois disso, não li mais. Li apenas em 1988. Hoje, não faço mais tradução alguma. Nesses anos todos, preferi exercer outras atividades, me dediquei mais à pesquisa. Poderia ter continuado no caminho da tradução se esta experiência tivesse sido gratificante, poderia ter me tornado tradutora, mas são escolhas que você faz. Não dá para fazer tudo ao mesmo tempo. Minha atividade principal é ser professora. Como parte do trabalho de professora numa universidade, você realiza uma pesquisa acadêmica. Se você se dedica plenamente à pesquisa, não sobra muito tempo para você se dedicar a outras atividades que têm diversas outras implicações, como a tradução. Outras pessoas exercem as duas atividades episodicamente. Conheço colegas nossos que traduzem de vez em quando. Mas, no meu caso, depois que eu fiz estas traduções, resolvi que não iria mais traduzir. Não gostaria de reler o livro e a tradução. Seria muito trabalhoso. Eu deixo isso para você fazer. Ver o original e a tradução e eventualmente elencar todos os defeitos.

30. Você acha que acabou por aceitar a proposta de tradução por ele se inserir no corpus das obras que você privilegiava na época? Se fosse uma obra de outra região ou outro país, você teria aceitado o desafio da tradução? O seu aceite se inscreve nos roupantes e nas alegrias das descobertas?

Acho que não. Acho que aceitei porque tinha gostado do romance. Antes de qualquer outro motivo, o fato de ter apreciado a obra foi o que me impulsionou. Eu ainda não tinha um traçado tão bem definido de estudar literatura antilhana. Não era um projeto muito claro. Era muito mais fruto das pesquisas do mestrado e das leituras desse período. Eu estava muito interessada pelas Antilhas, tinha ido à Mar- 
tinica em 1981 com a Maria Bernadette Porto ${ }^{6}$. Passamos um mês lá fazendo estágio. Conhecemos alguns escritores. Foi nesta viagem que eu comprei Ti Jean.

Além disso, na época, eu não recusava nada: cheguei a fazer tradução consecutiva do Ionesco diante da plateia lotada do teatro da Maison de France, plateia repleta de especialistas em teatro. Eu aceitava todos os desafios.

\section{Que sentimentos afloram nesse encontro com o romance tradu- zido trinta anos depois?}

Não se trata de nenhum sentimento negativo porque não sou alguém que costuma se lamentar. A tradução faz parte do meu percurso tanto quanto meu trabalho como intérprete numa época em que eu me sentia muito à vontade em francês. Do ponto de vista da expressão oral, falo hoje muito menos francês do que falava na época, não tenho mais a prática quotidiana de me expressar em francês. Não tenho, com relação à tradução, grandes emoções positivas ou negativas. Este trabalho que eu fiz deu oportunidade de muitas pessoas lerem o livro em português. Como qualquer outra tradução, teve sua importância. Eu não tenho mais muito presente lembranças sobre a experiência da tradução. Tudo está muito distante no tempo porque já faz mais de trinta anos que eu traduzi. Imagina isso. É uma vida. Tem a sua idade.

\section{Eurídice, nós estamos na sua biblioteca. O livro Ti Jean integra} o acervo que está aqui? Pergunto isto para entender os espaços afetivos. A tradução está disposta ao lado do original?

Deveria ser assim, mas eu tirei o livro da prateleira esta manhã para ver o ano de publicação. Ele estava nas prateleiras destinadas à literatura antilhana.

(Eurídice se levanta e me guia por suas estantes)

6 Professora titular de língua francesa e de literaturas francófonas da Universidade Federal Fluminense. 
- Aqui está a literatura francesa. Estas prateleiras são os livros das Antilhas. Tem três colunas de Antilhas. Eu peguei o livro hoje e folheei, mas não sei onde coloquei.

- Está aqui, Eurídice. Em cima desta pilha perto da estante.

-- Ele estava solto aqui, mas antes estava junto com os demais da Schwarz-Bart, aqui embaixo, em algum lugar aqui.

- Esta foi a edição que você usou para traduzir?

- Sim, esta é a única que eu tenho. (Eurídice folheia seu exemplar) Olha, todo anotado. Eu não vejo este livro há anos... (Silêncio) Sim, estão aqui. Tem mais dela. Tem também o Ton beau capitaine, Pluie et vent sur Télumée Miracle, Un plat de porc aux bananes vertes. Acabou. Depois tem a Gisèle Pineau. E a pilha da Maryse Condé que cresceu demais e não cabe mais aqui.

- Posso ver a edição em francês para observar algumas anotações? (Eurídice me estende o livro e eu volto para o sofá) [...] Fico encantada em poder ver isso: descobrir que tipo de palavra interpela, as marcas, os códigos de tradução: sublinhados, palavras circuladas; por exemplo, aqui na página 51, você assinalou "Nostr'homme".

- Você vê que é baseado em uma oralidade, mas trata-se sobretudo de uma poética. Eu fiz a ressalva ao lado deste parágrafo de "parole énigmatique" porque não se entende: "Il n'y a plus d'oiseau dans les nids de lan dernier et moi qui nai pas peur de la mort les poignards je les ôterai demain". O que se quer dizer com este trecho? Ela escreve bastante nesta linguagem repleta de enigmas dos contos, contos de fadas, contos fantásticos. Há trechos que não se tem como traduzir. $\mathrm{O}$ “nostr'homme" que você mencionou, é evidente que não tem. Eu não sei como traduzir.

(Eurídice folheia o livro. Eu observo o reencontro com a alegria de quem percebe a sorte de compartilhar da cena. Fico algum tempo em silêncio. Eurídice muda de expressão facial ao reler anotações do livro. Acaba 
ritmando a observação do original com algumas reações. De repente retoma a conversa:)

— O livro está até quebrado de tanto que eu manuseei na tradução. Está quebrado mesmo. [...] O coitado do livro ficou todo machucado, todo quebrado.

- Aqui você chegou a perceber até um erro na numeração dos capítulos no original.

- Pois é.

— Olha como esta página está assinalada.

— Não é necessariamente dificuldade de tradução, não. É o estudo do texto.

— Olha este provérbio: "Tu es allé à la chasse, nègre et tu as perdu le chien et l'agouti” . São dificuldades. Traduzir provérbio é extremamente difícil porque não há necessariamente um provérbio equivalente na outra língua. Aqui, outro provérbio: "Les lucioles brillent dans la nuit mais c'est pour éclairer leur âme, leur propre âme, avant celle du monde, dit le proverbe”. Você vê... O que será que é isso? É uma história muito fantástica esta do desaparecimento do sol. [...]

32. Dez anos após a publicação de Joãozinho no Além, você publica o estudo Construção de identidades pós-coloniais na literatura antilhana, em 1998. Houve algum movimento ao longo e após a tradução que se imprimiu no seu percurso de pesquisadora? A experiência de tradução contribuiu de que maneira para a continuidade de suas atividades universitárias?

Qualquer atividade intelectual contribui para nosso percurso. Uma tradução deste porte é sempre uma experiência de compreensão da obra, de reescrita. Nestas décadas de 1970, 1980 e 1990, eu realmente mergulhei nas obras antilhanas. Este livro foi uma parte do resultado deste trabalho, tanto do meu mestrado sobre Césaire quanto da leitura de outros autores que eu estava estudando como Chamoiseau, 
Glissant, Schwarz-Bart, Condé e Fanon. Foram quase duas décadas de estudos sobre os antilhanos. Eu li na época tudo o que eles tinham publicado até então.

33. Você tem conhecimento da reação e dos comentários de Simone Schwarz-Bart sobre a tradução brasileira da obra?

Não. Desconheço.

\section{Você se lembra de ter adotado o romance Ti Jean em um dos seus} cursos na universidade?

Eu não me lembro, mas eu diria que não. Eu adotei uma vez o Pluie et vent sur Télumée Miracle num curso da pós-graduação. Considero Télumée mais fácil para analisar em um curso porque tem a questão das mulheres, da loucura, da revolta contra os brancos. Ti Jean é muito bonito, mas muito complexo para ser integrado em um curso. Eu contava esta história do Ti Jean para o meu filho quando ele era pequeno na época em que eu estava traduzindo, contava do desaparecimento do sol. Meu filho nasceu no ano da publicação do romance, em 1979. Eu nem sabia desta coincidência. Vi hoje de manhã quando fui consultar o livro. Tudo isto é muito antigo. Não espere grandes revelações... É isso. That's it. 